Mariëtta van der Tol*

\title{
The "Jew," the Nation and Assimilation: The Old Testament and the Fashioning of the "Other" in German and Dutch Protestant Thought
}

https://doi.org/10.1515/jbr-2021-0013

Published online September 29, 2021

Abstract: This article discusses a reorientation of supersessionist postures in German and Dutch Protestant reflection on emerging nation states in the nineteenth-century. Historically, Christian thought often othered "the Jew" as the "nascent Christian." Since the seventeenth-century, Protestant theologians also entertained the possibility of theological othering on the basis of the legalism of the Mosaic covenant, of which ancient biblical Israel and its cultural liturgies were regarded as a token. In the context of the modern nation, German and Dutch Protestant thought entertained this typological othering of biblical nationhood to construct the modern Jew as "Gentile" to the modern nation. As "Gentile," "the Jew" remains the embodiment of the ultimate other, yet as "nascent Christian," modern Jews begin to face an unrelenting demand to assimilate. This conundrum contributed to a fundamental tension in the imaginary of the nation, namely between patterns of othering and structures of belonging, echoing far beyond antisemitism, and especially in patterns of othering that are inherent to racism and Islamophobia.

Keywords: nation, Jew, gentile, racial othering, assimilation

\section{Introduction}

Imaginaries of the nation have historically been imbued with supersessionist narratives: the status and normativity of the Old Testament have been central in theo-political discourses on the nation and its others. Supersessionism appears in different modalities: some may suggest the Old Testament to be irrelevant to the church of the New Testament; some may infer from the writings of St. Paul that

*Corresponding author: Mariëtta van der Tol, Alfred Landecker Postdoctoral Research Fellow, Blavatnik School of Government, Oxford, UK; and Junior Research Fellow, New College, Oxford, UK, E-mail: marietta.vandertol@bsg.ox.ac.uk 
Israel has lost its covenantal identity; and some may propound that the church has assumed the covenantal identity of ancient biblical Israel. ${ }^{1}$ This article discusses a reorientation of supersessionism in German and Dutch Protestant reflections on the rise of nation states from the nineteenth-century. It does so on the basis of two metaphors that are projected on the modern Jew: "the Jew" as "nascent Christian," and "the Jew" as "Gentile." "The Jew" as "nascent Christian" derives from the canonical tradition: canonical toleration, which formed the basis of early modern Christian thought on coexistence, understood and conditioned the toleration of Jews as a means to their eventual conversion and their acceptance of Jesus as the Messiah. ${ }^{2}$ Since the seventeenth-century, Protestant theologians also entertained the possibility of theological othering or disidentification ${ }^{3}$ on the basis of Mosaic legalism, signified by ancient biblical Israel and its cultural liturgies. ${ }^{4}$ In the context of the modern nation, German and Dutch Protestant thought entertained this typological othering of biblical nationhood to construct the modern Jew, as "the Jew, the Gentile" to the modern nation. As "Gentile," "the Jew" remains the embodiment of the other, yet as "nascent Christian," modern Jews begin to face an unrelenting demand to assimilate. This conundrum contributed to a fundamental tension in the imaginary of the nation, namely between patterns of othering or disidentification on the one hand, and structures of belonging, on the other

1 David Patterson, Anti-Semitism and Its Metaphysical Origins (Cambridge: Cambridge University Press, 2015), 65-73; Cf. Israel-forgetfulness or Israel-indifference in Kendall Soulen, The God of Israel and Christian Theology (Philadelphia: Fortress Press, 1996); Willie Jennings, The Christian Imagination: Theology and the Origins of Race (New Haven: Yale University Press, 2010), 32-33.

2 María J. Roca, “El concepto de tolerancia en el derecho canónico," Ius Canonicum 41, no. 82 (2001): 455-473, 460, 465; Julia Costa Lopez, "Beyond Eurocentrism and Orientalism: Revisiting the Othering of Jews and Muslims through Medieval Canon Law," Review of International Studies 42, no. 3, (2016): 450-470, 462; Rainer Forst, Toleration in Conflict (Cambridge: Cambridge University Press, 2013), 107-108; Gregory D. Dodds, "Betwixt Heaven and Hell: Religious toleration and the reception of Erasmus in England," in The reception of Erasmus in the early modern period, ed. Karl A.E. Enenkel (Leiden: Brill, 2013): 103-127, 109.

3 Aydan Gülerce, "Selfing as, with and without othering: dialogical (im)possibilities with Dialogical Self Theory," Culture \& Psychology 20, no. 2 (2014): 244-255; Jennings, The Christian Imagination, 45-59, citing Johannes Fabian, Time and the Other: How Anthropology Makes Its Object (New York: Columbia University Press, 1983), 18-31.

4 Ofri Ilany, In Search of the Hebrew People: Bible and Nation in the German Enlightenment (Bloomington: Indiana University Press, 2018), 3, 43-65; Anders Gerdmar, Roots of Theological Anti-Semitism: German Biblical Interpretation and the Jews, from Herder and Semler to Kittel and Bultmann (Leiden: Brill, 2010), 4, 9-12; Cf. Adrian Hastings, The Construction of Nationhood: Ethnicity, Religion and Nationalism (Cambridge: Cambridge University Press, 1997), 3-4, 186; Samuel Salzborn, "Ethnizität, Homogenität, Nation. Ein Spannungsverhaltnis," in Zur Lage der Nation. Konzeptuelle Debatten, gesellschaftliche Realitäten, internationale Perspektiven, ed. Carlo Masala (Baden-Baden: Nomos, 2018): 29-44, 41. 
hand - echoing far beyond antisemitism, and especially in patterns of othering that are inherent to racism and Islamophobia. ${ }^{5}$

The status of the Old Testament is central to the creation of this conundrum. ${ }^{6}$ The wide diversity of opinion in Protestant political thought on Jewishness and the nature of the nation, however, makes it impossible to distil a particular "Protestant" view. ${ }^{7}$ Based on conceptual analysis of secondary literature in political theory and biblical studies on the idea of the nation, the status of the Old Testament, and the typology of "the Jew," this article looks to three genealogically significant moments in German and Dutch Protestant political thought. Section 2 explores othering in early modern Christian thought (1550-1789) with specific reference to Samuel Pufendorf's (1632-1694) rejection of the relevance of the Old Testament to the post-Westphalian Christian state. He referred to the Old Testament and specifically his understanding of ancient biblical Israel as a nation in order to explain what the modern state is not. Section 3 discusses how the rationalization of morality in the works of Immanuel Kant (1724-1804), which implies a theological and racial disidentification with Jewishness, informs Schleiermacher's (1768-1834) antisemitic reception of the Old Testament, and reflects on the implications thereof for the status of "the Jew" in the German nation. This exploration is mirrored by a discussion of nationhood in relation to the Old Testament in the clash between the Dutch Reformed theologians Abraham Kuyper (1837-1920) and Philippus Hoedemaker (1839-1910). Whilst the Old Testament is important to them, it serves a different purpose: navigating supernaturalism and rationalism, as well as reimagining the role of the church in the rising nation state.

The reorientation of supersessionist postures in nineteenth-century German and Dutch Protestant thought has implications beyond the othering of the modern Jew. This reorientation needs to be read in conjunction with two relatively recent scholarly contributions. First, Kameron Carter's identification of the racialization of Jewish othering in Kant, which constructs Jewishness as the metaphor for all others, and, in whose thought "the Jew" comes at the bottom of the hierarchy of all others. ${ }^{8}$ Second, Willie Jennings' impressive critique of racism and othering in the

5 J. Kameron Carter, Race: a Theological Account (Oxford: Oxford University Press, 2008), 39-121; Jennings, The Christian Imagination, 26-27; Adam Silverstein, “Anti-Semitism and Islamophobia: Lessons from History," in Confronting Anti-Semitism and Islamophobia: An Exploration of their Socio-Historic and Theological Roots and Similarities, eds. Faissal Hameed and Mehri Niknam (London: Joseph Interfaith Foundation, 2011): 34-44, 44.

6 Klaus Beckmann, Die fremde Wurzel. Altes Testament und Judentum in der evangelischen Theologie des 19. Jahrhunderts (Göttingen: Vandenhoeck \& Ruprecht, 2002), 13; Yael Almog, Secularism and Hermeneutics (Philadelphia: University of Pennsylvania Press, 2019), 2-4.

7 Gerdmar, Roots of Theological Anti-Semitism, 15.

8 Carter, Race, 82-121. 
context of theologically inferred social imaginaries. On the basis of their work, Section 4 argues that theological antisemitism needs to be understood as a constitutive antecedent to othering in the nation state as well as the political concept of assimilation.

\section{Othering in Early Modernity: “The Jew" and Others as Nascent Christians}

Early modern Latin Christianity was obsessed about the unity of political entities. With the crippling of the old corpus christianum - a foundational political imaginary - smaller political entities started assuming its characteristics. ${ }^{9}$ Divided in corpora christiana, they entwined the oneness of the body of Christ with the normative interconnection and unity of land, people, and creed of smaller political entities. This transition is captured in the Westphalian treaties, to many the anchor of the modern state: they assumed political entities to be an unum corpus to themselves. ${ }^{10}$ In Politics of religious diversity: Toleration, religious freedom and visibility of religion in public space, I discussed how this process engendered a push for local uniformity: relegating the expression of competing identities to private spaces. ${ }^{11}$ This limited the potential of othered identities for cultural transcendence. ${ }^{12}$ Interpreting toleration as a spectrum of the visibility of otherness, I argued that the modern state and the nation state inherited a discomfort with the public manifestation of competing identities. What this thesis did not flesh out, is the enduring dependence of Latin Christian political imaginaries on its relationship with Jewishness and its deep concern over the question of whether or not modern political entities might be understood as heirs of ancient biblical Israel, as being chosen, and as agents of the kingdom of Christ.

The imaginary of the corpus christianum, ascribing varying theological significances to othernesses, co-constituted Christian identity negatively. Central

9 Mariëtta van der Tol, "Politics of religious diversity: toleration, religious freedom and visibility of religion in public space," University of Cambridge thesis, 1-3, 27-28. The ideas developed in this article build on van der Tol, "Politics of Belonging in the Nation State: Reclaiming Christianity from Populism" (rest of reference in footnote 26).

10 van der Tol, "Politics of religious diversity," 45; Article 5.43 Acta Pacis Westphaliae, Supplementa Electronica 1, Die Westfälischen Friendensverträge vom October 24, 1648. Text und Übersetzeungen, accessed May 5, 2017, http://www.pax-westphalica.de.

11 van der Tol, "Politics of religious diversity."

12 Harald Wydra, Politics and the Sacred, (Cambridge: Cambridge University Press, 2015), 43-49; Cf. Hubert Knoblauch, “Europe and Invisible Religion,” Social compass 50, no. 3 (2003): 267-274, 269. 
to this theological othering was the Jew, who was anticipated to convert to Christianity ("nascent Christian"), as well as the significance of the new covenant as such. This new covenant does not necessitate the abrogation of the Mosaic covenant (Jer 31:31-34), but Christian theology has tended to interpret the new covenant as inherent to the person of Christ. This covenant would never exist on a par with other covenants. This identification of the new covenant with the person of Christ is expressed in the Eucharist, and in particular, the element of wine as the blood of Christ. Following the words of institution and texts like Heb 8:8; Heb 8:13; Heb 12:24, the Communion service in the Book of Common Prayer says: "Drink ye all of this; for this is my Blood of the New Testament, which is shed for you and for many for the remission of sins." 13 Similar expressions are found in continental Reformed communion texts and prayers. As David Kline thoughtfully demonstrates, this focus on the Eucharist engendered concerns about purity in the body of Christ: theologically as well as socio-politically. ${ }^{14}$ This salvific economy implicitly negated the integrity of "the Jew" as permanently and exclusively Jewish - in soul and in body - as his teleology is necessarily bound to Christ in the Christian imagination.

Socio-politically, the toleration of "the Jew" depended on their anticipated conversion. ${ }^{15}$ However, the mission to Christianize the world still transcended "the Jew" as colonial histories show a similar concern over the conversion of Native Americans, Africans, and Black slaves, among others, as Willie Jennings demonstrates. ${ }^{16}$ Early modern Puritans regarded Native Americans as among the "Lost Tribes of Israel," needing to be called back to the true God, like the Jews. However, failure to convert led the same Puritans to make all sorts of comparisons with Amalek to legitimize violence against them. ${ }^{17}$ At once, the othering of "the Jew" is fundamentally different from the othering of the infidel, like the Muslim or the indigenous other, who were orientalized like the Jews, but whose existence posed no direct challenge to the legitimacy of the Christian covenant. ${ }^{18}$ The logic of

13 Church of England, The Book of Common Prayer: 1662 Version (Includes Appendices from the 1549 Version and Other Commemorations) (London: David Campbell, 1999), 116.

14 David Kline, Racism and the Weakness of Christian Identity (Oxford: Routledge, 2020), 99-130. 15 Dorit Wolf-Schwarz ed., Wege zur Toleranz. Geschichte einer europäischen Idee in Quellen (Darmstadt: Wissenschaftliche Buchgesellschaft, 2002), 211; Beckmann, Die fremde Wurzel, 23.

16 Jennings, The Christian Imagination, 15-38; Teresa M. Bejan, "When the Word of the Lord Runs Freely: Roger Williams and Evangelical Toleration,” in The Lively Experiment: Religious Toleration in America from Roger Williams to the Present, eds. Chris Beneke and Christopher S. Grenda (Lanham: Rowman \& Littlefield, 2015): 65-84, 65.

17 John Corrigan and Lynn S. Neal, eds., Religious Intolerance in America (Chapel Hill: University of North Carolina Press, 2010), 20-22.

18 Ilany, In Search of the Hebrew People, 27-34; Costa Lopez, "Beyond Eurocentrism," 462; István P. Bejczy, “Tolerantia: A Medieval Concept,” Journal of the History of Ideas 91, no. 4 (1997): 365384, 369, 375. 
toleration (and colonization) inhabited this posture of evangelization, violently if necessary. Thus, those who were othered were tolerated as "nascent Christians," whilst the idea that other religions would be a permanent part of the political community remained out of question. Instead, practices of dissimulation and state sanctioned limitation of public visibility began to determine the conditions of coexistence. ${ }^{19}$ Furthermore, deviancy within Christianity could justify intolerance, as could atheism on account of its defiance of the natural and divine. Heresy, infidelity, and Judaism were understood to be temporal states: atheism, failure to convert to Christianity, and apostasy challenged the Christian order inherently and therefore attracted fiercer persecution. ${ }^{20}$

The stratification of early modern othering was thus based on its theological significance. However, the "superiority" of Christian identity required a substantiation of Christian identity in distinction from Jewish identity as gleaned from the pages of the Bible. Whilst the stratification of othering and the deemed superiority of Christianity had no direct relation to the modern nation, the theological othering of the Jews rested on an explicitly negative construction of ancient biblical Israel, the idea of a forfeited covenant, and ultimately, the rejection of Israel as the covenant people of God. This, too, created the possibility to appropriate the idea of covenant in a (culturally) Christian political order, as Sophia Johnson discusses in this issue. And yet, the language of "nationhood" was not altogether alien to early modern consciousness. Adrian Hastings argued that the Christian world derived its ideas about nationhood and the status of nations from biblical imaginaries as early as in the post-medieval world, particularly in reference to the Old Testament. ${ }^{21}$ In this context, he defined the idea of the biblical nation as an ethnic community with a dynamic yet strong self-consciousness around a shared culture and liturgical language. ${ }^{22}$ This foreshadowed the centrality of language in nineteenth-century

19 van der Tol, "Politics of Religious Diversity," 23-24; Roca, "El concepto de tolerancia," 458, 460, 465; Bejczy, 'Tolerantia: A medieval concept', 375; Filomena Viviana Tagliaferri, Tolerance Re-Shaped in the Early-Modern Mediterranean Borderlands:, Missionaries, and Proto-Journalists (1683-1724) (New York: Routledge, 2018), Introduction; Stefania Tutino, "Between Nicodemism and 'Honest' Dissimulation: The Society of Jesus in England," Historical Research 79, no. 206 (2006): 534-553; Cf. Miriam Eliav-Feldon and Tamar Herzig, eds., Dissimulation and Deceit in Early Modern Europe (New York: Palgrave Macmillan, 2015); Peter Zagorin, Ways of Lying: Dissimulation, Persecution and Conformity in Early Modern Europe (Cambridge, Massachusetts: Harvard University Press, 1990).

20 Costa Lopez, "Beyond Eurocentrism," 455; Enzo Solari, “Contornos de la tolerancia medieval," Ideas y Valores 72, no. 153 (2003): 73-97, 81; Benjamin J. Kaplan, Divided By Faith: Religious Conflict and the Practice of Toleration in Early Modern Europe (London: Belknap Press, 2007), 12, 26, 71.

21 Hastings, The Construction of Nationhood, 186.

22 Hastings, The Construction of Nationhood, 3-4. 
ideas on nationhood. ${ }^{23}$ As Liah Greenfeld argues elsewhere in this issue, English translations of the Bible projected the language of the "nation" unto translations of the Old Testament, and from there this notion found its way into continental biblical translations. This seeming detail of the Reformation(s) is crucial to genealogies of nationhood, indicating a confluence of the European etymology of nationhood and theologized perceptions of nationhood, and explaining how the image of the nation entered into the popular consciousness well ahead of the nineteenth-century.

When the Westphalian settlements of 1648 conferred legitimacy to the imaginary of the corpus christianum with respect to separate political entities, a normative interconnection of land, people, and creed became part of international legal consciousness. Whilst the idea of the "nation" would not as yet surface with reference to European political entities, the theological understanding of the significance of ancient biblical Israel did inform the political imaginary of the corpus through the normative interconnection of land, people, and creed. ${ }^{24}$ However, the imaginary of the corpus was attached to the sovereignty of the political entity as such, and was not grounded in any conception of the nation. In this context, the primary question was how natural law related to the Mosaic law, and if the Mosaic law could be taken as an example to rising states. ${ }^{25}$ It is fascinating that debates over the status of the Old Testament prefigured some of the debates in nineteenthcentury Germany, when the connection between corpus and nation would emerge in reaction to eighteenth-century absolutism. ${ }^{26}$ As the Westphalian Peace treaties are widely regarded as the main precursor of the nation state, this connection between the imaginary of the corpus and the sovereignty of the political entity is genealogically crucial to understanding the significance of biblical hermeneutics to the rudiments of the nation state.

This significance is particularly evidenced from the political writings of the Reformed scholar Samuel Pufendorf, an eminent figure in European political thought and advisor to the King of Sweden, who acted as a guarantor of the Westphalian peace. In his tract of the Nature and Qualification of Religion in Reference to Civil Society, Pufendorf examined biblical themes in relation to the unity of a political community. ${ }^{27}$ He opened his tract with a discussion of the

23 Almog, Secularism and Hermeneutics, 35.

24 Almog, Secularism and Hermeneutics, 13.

25 Ilany, In Search of the Hebrew People, 46-65.

26 van der Tol, "Politics of Belonging in the Nation State: Reclaiming Christianity from Populism," in The Spirit of Populism: Political Theologies in Polarized Times, eds. Joshua Ralston and Ulrich Schmiedel (Leiden: Brill, 2021): 57-69.

27 Samuel von Pufendorf, On the Nature and Qualification of Religion in Reference to Civil Society (1687), trans. Jodocus Crull, ed. Simone Zurbruchen (Indianapolis: Liberty Fund, 2002). 
organization of religion before the institutions of what he called "civil societies" with exclusive reference to ancient biblical Israel, and used this to qualify his understanding of natural law. ${ }^{28} \mathrm{He}$ relied on his reading of the Old Testament and interpreted ancient biblical Israel as temporally and theologically prior to both Christianity and contemporary Christian political communities. Pufendorf also discussed the normative interconnection of land, people, and creed from the perspective of ancient biblical Israel. Central to his discussion is the comparison between the giving of the law at Mount Sinai, the recapitulation of creation in Christ, as well as the fundamental incomparability of ancient biblical Israel and the state. Pufendorf seemed to have assumed the biblical terminology of the nation, but he used this language to refer to what contemporary political communities are not and ought not to be.

In his understanding, Jews were keepers of the law and the prophets until the coming of Christ. ${ }^{29}$ In order to fulfill this task, their religion and state were completely united, under the condition that the land would only be inhabited if the whole people of Israel maintained the law. ${ }^{30}$ Nineteenth-century biblical criticism would understand this narrative as Deuteronomic as well as Priestly, but source dating was obviously unknown to Pufendorf in his early modern context. To him, this unity of religion and state was "so entire, that the first could not remain standing, after the fall of the last; and that therefore the destruction of the Temple, and of the Commonwealth of the Jews, was an infallible Sign of the total abolishment of their Religion." 31 This narrative of the relationship between Christ and the Old Testament is clearly supersessionist and understands the Mosaic covenant as obsolete in the light of Christ. However, Pufendorf did not understand new states as direct successors of covenant Israel. He observed that Israelite priests came from the particular tribe of Levi, none of whom were allotted any land. Similarly, Christ had nowhere "to lay his head." And whereas "Christians in general are called Priests before God," no automatic connection between religion and land would exist. ${ }^{32}$

Equally, there was no automatic connection between Christianity and nationhood. Pufendorf wrote: "Lastly, Each Nation has an equal share in the Christian Religion; neither can any of them claim a peculiar Right or Prerogative before others, every one having equal share in the Merits of Christ." ${ }^{33}$ This assertion

\footnotetext{
28 von Pufendorf, On the Nature and Qualification of Religion, §1-2, 5, $6 \mathrm{ff}$.

29 von Pufendorf, On the Nature and Qualification of Religion, §9.

30 von Pufendorf, On the Nature and Qualification of Religion, §9, 10.

31 von Pufendorf, On the Nature and Qualification of Religion, $\$ 9$.

32 von Pufendorf, On the Nature and Qualification of Religion, §9, 10, 11, 15.

33 von Pufendorf, On the Nature and Qualification of Religion, \$11.
} 
is followed by a quotation from Colossians 3, which states that in Christ there is "neither Jew nor Greek:" this understanding of the New Testament not only rendered the use of the Mosaic Covenant and the Israelites irrelevant to the state, it proceeded to deny the integrity of Jewishness outside of the Christian order. ${ }^{34}$ Pufendorf argued against the assumption of the corpus christianum with regard to the formation of states and especially the connection with princes. The New Testament church needed no sovereign, state, or the support of state authority. ${ }^{35}$ Moreover, he concluded that there is no justification for maintaining unity through religious uniformity, which he assumed to be a feature of the Mosaic Covenant. ${ }^{36}$

His interpretation is a powerful critique of the normative interconnection of law, people, creed, as well as uniformity within a political community, and thus forms a vital contribution to the development of toleration. The fact that his tract started with a discussion of nation, land, people, and uniformity testifies to the broader currency of these biblical concepts in post-Westphalian political thought. And whereas his proto-democratic reasoning refused to project a narrative of ancient biblical Israel onto statehood, he still relied on a distinct biblical hermeneutic to argue against it. The figure of Christ, in his interpretation, rendered the Old Testament inferior to the New Testament and implicitly reduced the significance of Jewishness, even to "the Jew." In other words, he criticized one type of supersessionism with another one: he did reject using ancient biblical Israel as a model for the state, but he did not escape the modality of supersessionism in which the Jew continues to be fashioned as the "nascent Christian," with no relevant and enduring socio-political Jewish identity.

\section{The Jew as the Gentile and the Nascent Christian in Nineteenth-Century Protestant Political Thought}

While the rise of nation states is associated with the late eighteenth and early nineteenth-century, ideas about nationhood already existed in popular consciousness because of its biblical references. Philosophically, the concept of nationhood emerged as a response to, and repudiation of, eighteenth-century absolutism, vesting sovereignty not in the monarch, but in "the people." The rupture that the French Revolution represents allowed for a reorientation of the

34 von Pufendorf, On the Nature and Qualification of Religion, §11.

35 von Pufendorf, On the Nature and Qualification of Religion, §28-35, 17.

36 von Pufendorf, On the Nature and Qualification of Religion, §30. 
normative interconnection of land, people, and creed towards the imaginary of nationhood. However, the novelty of the nation state obscured the genealogical kinship between the oneness of the corpus christianum and nation, which several constitutions proclaim to be "one" and "indivisible." ${ }^{37}$ In this context, the previous association of Jewishness with nationhood facilitated the construction of the Jew as part of another nation, and thus "Gentile" relative to new nations. ${ }^{38}$ It is this logic which explains the idea that the "Republic had to grant everything to Jews as individual citizens and nothing as a community;" 39 as well as Napoleon's echo thereof denouncing collective Jewish identity as a "nation within a nation."40 Instead, Napoleon emphasized the necessity of Jewish acculturation and assimilation, the moderation of transnational narratives about Zion, as well as his vision of a "pure" kind of Frenchness. ${ }^{41}$

This continued othering also occurred in German Protestant political thought. Kameron Carter understands Kant's Anthropology as a genealogical moment in this racialization of the nation state's others. ${ }^{42}$ Carter expertly analyses how Kant's construction of the rational human being implies the construction of hierarchies of being in which Jewish identity is, at least functionally, the proto-other: an overly reverent posture towards religious law would preclude them from rational engagement with the needs of a political community. ${ }^{43}$ Their presumed inferior receptivity to rationality and thus self-cultivation would obstruct the genesis of the new nation and the development of the nation as one (Christian) ethical community. ${ }^{44}$ Nonetheless, he recognized that the "one (true) religion" (sic!) could find expression in Judaism as it would in other non-Christian faiths, and that the ethical

37 Van der Tol, "Politics of Belonging," 1.

38 Beckmann, Die fremde Wurzel, 24.

39 Cited in Jocelyne Cesari, “Unexpected Convergences: Religious Nationalism in Israel and Turkey," Religions 9, no. 11 (2018): 334-354, comments by Comte de Clermont-Tonnerre (1747-1792) and the Abbe Gregoire (1750-1831).

40 Joshua Schreier, "Napoléon's Long Shadow: Morality, Civilization, and the Jews in France and Algeria, 1808-1870," French Historical Studies 30, no. 1 (2007): 77-103, 78, 81. The Assembly of Jewish Notables, renamed the Grand Sanhedrin focused on legal harmonization in the period leading up to the 1808 decrees (78); Jonathan Frankel, "Assimilation and the Jews in NineteenthCentury Europe: Towards a New Historiography?,” in Assimilation and Community: The Jews in Nineteenth-Century Europe, eds. Jonathan Frankel and Steven J. Zipperstein, (Cambridge: Cambridge University Press, 1992): 1-37, 11.

41 Frankel, "Assimilation and the Jews," 12; Schreier, "Napoléon's Long Shadow," 80-82, 102-103.

42 Carter, Race, 80.

43 Cf. Jan Veenhof, Revelatie en Inspiratie. De Openbarings-en Schriftbeschouwing van Herman Bavinck in vergelijking met die der ethische theologie (Amsterdam: Buijten \& Schipperheijn, 1968), 33. 44 Carter, Race, 109. 
content was sufficient for the purposes of coexistence. ${ }^{45}$ But it was not compatible with the higher calling of the nation. Jewishness is thus constructed as incompatible with the imperative of reason and the flourishing of the nation. Carter continues to lay out how Kant's antisemitism utilized race as well as orientalism, to the extent that "the Jew" became the metaphor for all others. ${ }^{46}$ But, Carter writes, "what sets the Jews apart, however, from the other alien, nonwhite races, the alien beyond Europe, is this racial alien, Kant in effect says, is living among us." ${ }^{47}$ What is crucial to note is that this problematization of presence is associated with the teleology of nationhood, and not necessarily with coexistence as such. In Kant's teleology of the nation, the othering of and disidentification with Jews is strong: "the Jew" ceases to be just a "nascent Christian" and begins to function like a "Gentile" relative to the nation as well.

Kant's conceptualization of Jewish identity echoes in German Protestant political thought; first, in relation to the authority of Scripture and second, with respect to the possibility of Jewish citizenship. The picture that emerges, I argue, is one in which the Jew simultaneously is the "Gentile" and the "nascent Christian." Though the discussion focusses on the status of the Old Testament, like in Pufendorf, the theological matter at hand is a collision of supersessionism and the Kantian conceptualization (and dehumanization) of the Jew. As Klaus Beckmann demonstrates, this surfaced most visibly in the work of the early Schleiermacher. Schleiermacher characterizes the Jew as the child - à la Lessing and Spinoza - who has no capacity to exist as an autonomous being and therefore allegedly lacked the self-consciousness necessary to function as a capable citizen - à la Herder. ${ }^{48}$ According to Beckmann, Schleiermacher framed the Old Testament as a Jewish book with no direct relevance to the church, other than a hermeneutic source towards interpreting the New Testament. ${ }^{49}$ However, Paul Capetz observes that Beckmann's theological commitment to a christocentric reading of the Bible prevents him from a sharper criticism of Schleiermacher's approach to the Old Testament. Schleiermacher used to emphasize the integrity of historical religious

45 Immanuel Kant, Religion within the Limits of Reason Alone [1793], trans. Theodore M. Greene (New York: Harper Torchbooks, 1960), 98-100; Carter, Race, 91-93; David Heyd, "Is Toleration a Political Virtue?,” in Toleration and its Limits, eds. Melissa S. Williams and Jeremy Waldron (New York: New York University Press, 2008): 171-194, 181.

46 Some Jewish communities embraced orientalism as a mock name for an honorary title, see Ivan Kalmar, "Jews, Cousins of Arabs: Orientalism, Race, Nation, and the Pan-Nation in the Long Nineteenth Century," in Is there a Judaeo-Christian tradition? A European perspective, eds. Emmanuel Nathan and Anya Topolski (Berlin: De Gruyter, 2015): 53-73.

47 Carter, Race, 105 (emphasis mine).

48 Beckmann, Die fremde Wurzel, 35-39, 43-47; Ilany, In Search of the Hebrew People, 21.

49 Beckmann, Die fremde Wurzel, 54-57, 312-315. 
communities, for he failed to distinguish between pre-exilic and post-exilic elements of the Old Testament. This led him to overlook the diversity that existed within Jewish communities before the rise of rabbinic or "orthodox" Judaism, and caused him to conceive of Jewish identity as a unified ethno-religious community. ${ }^{50}$

It is only his methodological differentiation of the "ethical" from the "religious" 51 that he was able to marry his disdain for the Old Testament Jew with his sympathy for the idea of Jewish citizenship. On the level of the "religious," he saw no future for the Jew as theologically committed to (his imagination of) Jewishness. ${ }^{52}$ However, as a theologian and pastor, he was worried about pseudoconversion for civic gain. Instead, he suggested that it follows from reason that it should be possible to be a citizen without being Christian: "Die Vernunft fordert, daß Alle Bürger sein sollen, aber sie weiß nichts davon, daß Alle Christen sein müßen, und es muß also auf vielerlei Art möglich sein, Bürger, und Nichtchrist zu sein (...)” [Reason demands that everyone should be citizens, but she has nothing to do with a demand that everyone should be Christian, and it should be entirely possible to be a citizen and not to be Christian]. ${ }^{53}$ Thus, on the level of the "ethical," like Kant, he affirmed the possibility of citizenship. In this sense, Schleiermacher, as well as Kant, was more open to Jewish emancipation than figures like Herder and Semler. However, Schleiermacher did expect Jews to assimilate; perhaps not sanctioned by political pressure, but certainly through Bildung. Ruth Ravenscroft shows that this confluence of the cultural and the political limits the potential for the distinction between the ethical and the religious to arrive at a conception of citizenship that is free from the pressures of assimilation. ${ }^{54}$ Note that this assimilation inhabits a culturalized, and to some extent secularized, iteration of the Jew as the "nascent Christian." 55 This is crucial to the conversation about assimilation, especially as Schleiermacher regarded the Jews as the most important example of non-Christian religion. ${ }^{56}$ Schleiermacher's writings had an enormous impact in Protestant circles in Germany, as well as the Netherlands.

50 Paul E. Capetz, "Friedrich Schleiermacher on the Old Testament," The Harvard Theological Review 102, no. 3 (2009): 297-325, 304-309.

51 Ruth Ravenscroft, The Veiled God (Leiden: Brill, 2019), 34-35.

52 Beckmann, Die fremde Wurzel, 47.

53 Friedrich Schleiermacher, "Briefe bei Gelegenheit der politisch theologischen Aufgabe und des Sendschreibens jüdischer Hausväter," [1799], in Schleiermacher. Kritische Gesamtausgabe, Band II, ed. Hans-Joachim Birkner (Berlin: De Gruyter, 1984): 327-362, 335 (translation mine).

54 Ravenscroft, The Veiled God, 253-255.

55 Beckmann, Die fremde Wurzel, 77-79, 133-135, 328-330; Cf. Ilany, In Search of the Hebrew People, 4-12.

56 Beckmann, Die fremde Wurzel, 324. 
In the Netherlands, the status of the Old Testament was the subject of a Reformed quarrel over the Christian character of the nation and the position of the Jews and others therein. ${ }^{57}$ Protagonists of this quarrel were the theologians Abraham Kuyper and Philippus Hoedemaker. Hoedemaker believed the nation ought to be Christian, whereas Kuyper argued that the nation could not possibly be Christian because of the existing religious diversity. Kuyper distinguished between "people" and "nation," understanding the latter as an organism and a "community by blood" that operates as a "coherent unity" by means of language and culture. ${ }^{58}$ Speaking about "the Jews," he recognizes that "nobody hesitates to speak of a Jewish people, even though everyone knows that Jews are scattered all over the earth" and that it is barely possible to speak of them as "one coherent community." 59 Because of the differences between the diasporic communities, Jews cannot be conceived to be "a nation." ${ }^{60}$ But he does not flesh out if specific Jewish communities might be understood as nations. What is clear is that Jews cannot be part of "the nation," and could only remain "guests."61 Instead, he considers Jews, along with Arabs and traveler communities, in the context of the "other" to the nation. Kuyper's attitude to the Jews was outrightly disparaging and antisemitic. He wielded stereotypes of either rich or degenerate Jews, and framed the liberalization of society pejoratively as "judaisation." 62 But it would be too quick to align this othering with his antisemitism, even though they are obviously connected. Kuyper clarifies that "it is out of the people that the state emerges, creating a bond between everyone." 63 This rationale led him to affirm the citizenship rights of Jews, like Schleiermacher, but he goes a step further in affirming a normative bond between all citizens, formally irrespective of what might be understood to be the nation.

Kuyper's religious tradition, however, was incompatible with his political pluralism. Kuyper therefore implored a revision of Article 36 of the Belgic Confession akin to the moderation of the Westminster Confession, which detailed

57 This section builds on Van der Tol, "Politics of Belonging."

58 Abraham Kuyper, Antirevolutionaire Staatkunde. De Beginselen (Kampen: Kok, 1916), 145-148.

59 "Niemand aarzelt om te spreken van het Joodsche volk, al weet met, dat de Joden verstrooid zijn over de geheele aarde en er nauwelijks van eenig algemeen verband onder hen meer sprake is", Kuyper Antirevolutionaire Staatkunde, 148 (translation mine).

60 Kuyper, Antirevolutionaire Staatkunde, 148-149.

61 Bart Wallet, "Waarom het antisemitisme uiteindelijk niet aansloeg in de Nederlandse Christelijk-Sociale traditie," Sophie 3 (2016): 4; Philippus J. Hoedemaker, Article 36 of the Belgic Confession VINDICATED against Dr. Abraham Kuyper, 1901, trans. Ruben Alvarado (Aalten: Pantocrator Press, 2019), 63.

62 Wallet, "Waarom het antisemitisme uiteindelijk niet aansloeg," 4-5.

63 Kuyper, Antirevolutionaire Staatkunde, 150. 
the vocation of secular authorities not only to promote true religion, but also to destroy false religion. ${ }^{64}$ Kuyper relied on arguments pertaining to the Old Testament; for example, he argued that "the church did not supersede Israel" and he "questioned the relevance of the Old Testament to political theology" more in general. ${ }^{65}$ Hoedemaker, on the other hand, was a fierce proponent of religious conformity, and stated that "our nation is a Christian, Protestant, Reformed nation and that all principled parity between belief and unbelief $(. .$.$) is ruled out from the$ start." 66 To him, the others to the nation are both Jews and Roman Catholics. Moreover, the erroneous separation of church and state would be based on an institutional rather than essentialist ecclesiology. ${ }^{67}$ In a clever attempt to portray Kuyper as full-on Schleiermachian, Hoedemaker writes: "It is as if someone commencing an investigation into the history of clothing would say 'By clothing, I mean a gentleman in a sport coat or suit, or a lady in a ballroom dress or a gown,' in order to avoid any connection to the animal skins in the Garden of Eden." ${ }^{68}$ In the background hovers the skepticism of Dutch Reformed theologians on all things Schleiermachian: a concern over increasing tensions between reason and revelation, as well as the divine inspiration of Scripture. ${ }^{69}$ In either perspective, however, the connection between state and Christianity remains fundamentally uncontested, even as Kuyper formulated a more inclusive political theology and rejected the idea of Christian nationhood as such.

Amidst the heavy theological polemics hides a rather fundamental difference in the fashioning of "the other" in the Dutch and German contexts: Kuyper and Hoedemaker both considered the Jew in the context of "the other," whereas German Protestant theologians like Scheiermacher tended to understand "the other" in the context of the Jew. Nonetheless, "the Jew" remains an outsider, "the Gentile" to the nation, with or without citizenship rights. And "the Jew" is expected to adjust, to emancipate, if not to assimilate. This is of course reminiscent of the metaphor of "the Jew" as "the nascent Christian" - even if in the context of the

64 Abraham Kuyper, "Calvinism and Confessional Revision," The Presbyterian and Reformed Review 2, no. 7 (1891): 369-399; Abraham Kuyper, Calvinisme en revisie (Amsterdam: Wormser, 1891).

65 Vincent E. Bacote, The Spirit in Public Theology: Appropriating the Legacy of Abraham Kuyper (Grand Rapids, Michigan: Baker Academic, 2005), 108; Kuyper, Antirevolutionaire Staatkunde. De Beginselen (Kampen: Kok, 1916), 273, 469-474; Abraham Kuyper, Calvinism: Six Stone Lectures (Amsterdam: Höveker \& Wormser, 1898), 107-108; Abraham Kuyper, Locus de Magistratu (Kampen: Kok, 1900), 259.

66 Hoedemaker, Article 36, 31, 44, 58, 62, 90-91, esp. 62.

67 Hoedemaker, Article 36, 42.

68 Hoedemaker, Article 36, 44.

69 Veenhof, Revelatie en Inspiratie, 11-28. 
nation this identity begins to be secularized. What emerges is a theologically complex and conflicted relationship between the nation, the Jew, and the Old Testament: they are troubled theologies of belonging. The difference in the fashioning of "the other" matters to Carter's argument; it shows how Kant's pseudotheological othering of the Jew is discussed, and to some extent appropriated, by theologians. This is something that Protestant traditions ought to reckon with. However, the myriad of responses that theologians have produced, and of which this article has only surveyed a small yet significant part, suggests that the reception of Kant's political-theological imagination of the other might be more complex than Carter's theorization allows for. Nevertheless, the antisemitism and related modes of othering that he discerns ought to be taken seriously.

\section{Conclusion: The "Nascent Christian" as the Theological Antecedent of Assimilation}

The philosophical and theological Judaization of otherness in the nation has two particular manifestations: first, the Jew appears as (natural) "Gentile" to the nation; second, insofar as political thought in and outside of Protestant circles conceived of Jewish citizenship, this membership was grounded in the assumption that the Jew has no future in the nation as Jew, but must (to an extent) assimilate. Based on Carter's observation concerning the broader significance of Jewish othering, the implication would be that every "other" symbolically remains at once "Gentile” and "nascent Christian.” Or as Jennings puts it in the chapter "Zurara's Tears:" "The author, in recounting his travels to different places, notes several times that the people are black, or black as pitch. They are Christian, yet they are black." ${ }^{70}$ In contemporary language, this is expressed through the concerns of assimilation, which echo most obviously with regards to Muslims in Europe, for example where it is said that a woman who wears a hijab cannot be German. ${ }^{71}$ Or, as Strømmen and Schmiedel note, the reality that Muslims are often assumed to be culturally or religiously different, to be born abroad, or to be associated with other nationalities. ${ }^{72}$ The reality is also that the same woman without a hijab may still be

70 Jennings, The Christian Imagination, 23.

71 Rudolf Steinberg 2015 in "Toleranz und religiose Pluralität am Beispiel von Kopftuch und Burka,” accessed March 25, 2021, http://www.rudolf-steinberg.de/media/toleranz_und_ religioese_pluralitaet-ohnefn.301115_1.pdf.

72 Hannah Strømmen and Ulrich Schmiedel, The Claim to Christianity. Responding to the Far Right (London: Student Christian Movement [SCM] Press, 2020), 20. 
racialized as Muslim. ${ }^{73}$ This is not coincidental: it is part of the same insoluble contradiction of the perpetual othering and the perpetual call to assimilate. ${ }^{74}$ In the Schmittian tradition, political concepts tend to be understood as secularized theological ideas, however, I would like to suggest that the narrative of the Jew as the nascent Christian is an important and enduring theological antecedent of the political concept of assimilation. ${ }^{75}$

Let me first elaborate on what this antecedental relationship does not mean. Philosophical and theological Judaization of otherness does not imply that nonJewish others are identically othered to Jews. Whereas the concept of assimilation derives from the Jew as both "Gentile" and "nascent Christian" and as such may refer to a wider range of "others" - this does not mean that we can generalize the experience of what it means to assimilate. I believe such generalized comparisons between Jewish, Muslim, Catholic, Black othering are not actually fruitful as they tend to overlook social, economic, and political challenges as well as intersectionality with gender, ethnicity, race, ability, and so forth. For this reason, I do not find Strømmen and Schmiedel's characterization of Islamophobia as the "new racism" particularly helpful, other than that it carries an effective normative rhetorical force. ${ }^{76}$ Historically, it might be more accurate to speak of the many resonances of antisemitism in relation to the formation of national identity. Crucially, Karin Stögner warns that the theory of intersectionality does not sufficiently address antisemitism, as Jewish identities exist beyond the usual (binary) codes of gender, religion, race, and so forth. She writes: "We have to understand the banality that in antisemitism everything can be interpreted against the Jews." Her reference to "everything" is a poignant echo of the Jew being constructed as the complete other to the nation. This in itself is a profoundly troubling conclusion, especially as antisemitism is again on the rise throughout Europe. Moreover, the philosophical and theological Judaization of otherness does not mean that their metaphysical significance is identical either.

73 Nandita Sharma, “Racism," in Citizenship and its Others: Migration, diasporas and citizenship, eds. Bridget Anderson and Vanessa Hughes (Basingstoke: Palgrave Macmillan, 2015): 98-118; cf. Sara Lei Sparre, "(In)visibility and the Muslim Other: Narratives of Flight and Religious Identity among Iraqi Christians in Denmark,” Ethnicities 21, no. 3 (2020): 589-610.

74 van der Tol, "Politics of Religious Diversity," ch. 5.

75 Carl Schmitt, Political Theology: Four Chapters on the Concept of Sovereignty, trans. G. Schwab (Chicago: University of Chicago Press, 1985), 36.

76 Strømmen and Schmiedel, The Claim to Christianity, 20-21.

77 Karin Stögner, "Intersectionality and Antisemitism - A New Approach,” Fathom, May Stögner 2020, accessed March 22, 2021, https://fathomjournal.org/intersectionality-and-antisemitism-anew-approach/, conclusion. 
When I say that the narrative of the Jew as the nascent Christian is an important political-theological antecedent to the political concept of assimilation, I refer to the political imaginaries that structurally underpin assimilation, and which have been co-constituted and amplified through political theologies, past and present. This structure is twofold: the first structure is the designation of certain characteristics as fundamentally other or "Gentile," incompatible with the identity of the nation. The second structure is the assumption that integration is a process of acculturation that is subject to the negation of one's previous (and perpetually incompatible) identity. Whilst the experience of newcomers cannot be generalized in concreto, the structures in abstracto are shared between Jews, Muslims, foreigners, and a range of othered identities. The metaphor of the nascent Christian, with its early modern associations of dissimulation and the imperative of religious conformity, is especially poignant as "nascence" indicates something that is beginning, emerging, embryonic, but which never outgrows its nascence. In other words, assimilation does not mitigate the fundamental othering that underlies it because they concern two different structures. As a result, no measure of integration or assimilation may actually engender authentic belonging insofar as the political community remains imaginarily closed to its others. The implication thereof is that discourses of integration can only veil and obscure the persistent and underlying othering that is inherent to the imaginary of the nation.

\section{References}

Almog, Y. 2019. Secularism and Hermeneutics. Philadelphia: University of Pennsylvania Press. Bacote, V. E. 2005. The Spirit in Public Theology: Appropriating the Legacy of Abraham Kuyper. Grand Rapids, Michigan: Baker Academic.

Beckmann, K. 2002. Die fremde Wurzel. Altes Testament und Judentum in der evangelischen Theologie des 19. Jahrhunderts. Göttingen: Vandenhoeck and Ruprecht.

Bejan, T. M. 2015. "When the Word of the Lord Runs Freely: Roger Williams and Evangelical Toleration." In The Lively Experiment: Religious Toleration in America from Roger Williamsto the Present, edited by C. Beneke, and C. S. Grenda, 65-84. Lanham: Rowman \& Littlefield. Bejczy, I. P. 1997. “Tolerantia: A Medieval Concept.” Journal of the History of Ideas 91 (4): 365-84. Capetz, P. E. 2009. “Friedrich Schleiermacher on the Old Testament.” The Harvard Theological Review 102 (3): 297-325.

Carter, J. K. 2008. Race: A Theological Account. Oxford: Oxford University Press.

Cesari, J. 2018. “Unexpected Convergences: Religious Nationalism in Israel and Turkey." Religions 9 (11): 334-54.

Corrigan, J., and L. S. Neal, eds. (2010). Religious Intolerance in America. Chapel Hill: University of North Carolina Press. 
Costa Lopez, J. 2016. "Beyond Eurocentrism and Orientalism: Revisiting the Othering of Jews and Muslims through Medieval Canon Law.” Review of International Studies 42 (3): 450-70.

Dodds, G. D. 2013. "Betwixt Heaven and Hell: Religious toleration and the reception of Erasmus in England." In The Reception of Erasmus in the Early Modern Period, edited by K. A. E. Enenkel, 103-27. Leiden: Brill.

Eliav-Feldon, M., and H. Tamar, eds. (2015). Dissimulation and Deceit in Early Modern Europe. New York: Palgrave Macmillan.

Fabian, J. 1983. Time and the Other: How Anthropology Makes Its Object. New York: Columbia University Press.

Forst, R. 2013. Toleration in Conflict. Cambridge: Cambridge University Press.

Frankel, J. 1992. "Assimilation and the Jews in Nineteenth-Century Europe: Towards a New Historiography?" In Assimilation and Community: The Jews in Nineteenth-Century Europe, edited by J. Frankel, and S. J. Zipperstein, 1-37. Cambridge: Cambridge University Press.

Gerdmar, A. 2010. Roots of Theological Anti-Semitism: German Biblical Interpretation and the Jews, from Herder and Semler to Kittel and Bultmann. Leiden: Brill.

Gülerce, A. 2014. "Selfing As, With and Without Othering: Dialogical (Im)possibilities with Dialogical Self Theory." Culture \& Psychology 20 (2): 244-55.

Hastings, A. 1997. The Construction of Nationhood: Ethnicity, Religion and Nationalism. Cambridge: Cambridge University Press.

Heyd, D. 2008. "Is Toleration a Political Virtue?" In Toleration and its Limits, edited by M. S. Williams, and J. Waldron, 171-94. New York: New York University Press.

Hoedemaker, P. J. 2019. Article 36 of the Belgic Confession VINDICATED against Dr. Abraham Kuyper, 1901, trans. R. Alvarado. Aalten: Pantocrator Press.

Ilany, 0. 2018. In Search of the Hebrew People: Bible and Nation in the German Enlightenment. Bloomington: Indiana University Press.

Jennings, W. 2010. The Christian Imagination: Theology and the Origins of Race. New Haven: Yale University Press.

Kalmar, I. 2015. "Jews, Cousins of Arabs: Orientalism, Race, Nation, and the Pan-Nation in the Long Nineteenth Century." In Is there a Judaeo-Christian tradition? A European perspective, edited by E. Nathan, and A. Topolski, 53-73. Berlin: De Gruyter.

Kant, I. 1960. Religion within the Limits of Reason Alone [1793], trans. T. M. Greene. New York: Harper Torchbooks.

Kaplan, B. J. 2007. Divided By Faith: Religious Conflict and the Practice of Toleration in Early Modern Europe. London: Belknap Press.

Kline, D. 2020. Racism and the Weakness of Christian Identity. Oxford: Routledge.

Knoblauch, H. 2003. "Europe and Invisible Religion." Social compass 50 (3): 267-74.

Kuyper, A. 1891a. "Calvinism and Confessional Revision.” The Presbyterian and Reformed Review 2 (7): 369-99.

Kuyper, A. 1891b. Calvinisme en revisie. Amsterdam: Wormser.

Kuyper, A. 1898. Calvinism: Six Stone Lectures. Amsterdam: Höveker \& Wormser.

Kuyper, A. 1900. Locus de Magistratu. Kampen: Kok.

Kuyper, A. 1916. Antirevolutionaire Staatkunde. De Beginselen. Kampen: Kok.

Lei Sparre, S. 2020. "(In)visibility and the Muslim Other: Narratives of Flight and Religious Identity among Iraqi Christians in Denmark." Ethnicities 21 (3): 589-610.

Patterson, D. 2015. Anti-Semitism and Its Metaphysical Origins. Cambridge: Cambridge University Press. 
von Pufendorf, S. 2002. On the Nature and Qualification of Religion in Reference to Civil Society [1687], trans. J. Crull, edited by S. Zurbruchen. Indianapolis: Liberty Fund.

Ravenscroft, R. 2019. The Veiled God. Leiden: Brill.

Roca, M. J. 2001. “El concepto de tolerancia en el derecho canónico." Ius Canonicum 41 (82): 455-73.

Salzborn, S. 2018. “Ethnizität, Homogenität, Nation. Ein Spannungsverhaltnis.” In Zur Lage der Nation. Konzeptuelle Debatten, gesellschaftliche Realitäten, internationale Perspektiven, edited by C. Masala, 29-44. Baden-Baden: Nomos.

Schleiermacher, F. 1984. "Briefe bei Gelegenheit der politisch theologischen Aufgabe und des Sendschreibens jüdischer Hausväter.” [1799]. In Schleiermacher. Kritische Gesamtausgabe, Vol. II, edited by H.-J. Birkner, 327-62. Berlin: De Gruyter.

Schmitt, C. 1985. Political Theology: Four Chapters on the Concept of Sovereignty, trans. G. Schwab. Chicago: University of Chicago Press.

Schreier, J. 2007. "Napoléon's Long Shadow: Morality, Civilization, and the Jews in France and Algeria, 1808-1870.” French Historical Studies 30 (1): 77-103.

Sharma, N. 2015. "Racism." In Citizenship and its Others: Migration, diasporas and citizenship, edited by B. Anderson, and V. Hughesa, 98-118. Basingstoke: Palgrave Macmillan.

Silverstein, A. 2011. "Anti-Semitism and Islamophobia: Lessons from History." In Confronting AntiSemitism and Islamophobia: An Exploration of their Socio-Historic and Theological Roots and Similarities, edited by F. Hameed, and M. Niknam, 34-44. London: Joseph Interfaith Foundation.

Solari, E. 2003. “Contornos de la tolerancia medieval.” Ideas y Valores 72 (153): 73-97. Soulen, K. 1996. The God of Israel and Christian Theology. Philadelphia: Fortress Press.

Steinberg, R. 2015. Toleranz und religiose Pluralität am Beispiel von Kopftuch und Burka. http:// www.rudolf-steinberg.de/media/toleranz_und_religioese_pluralitaet-ohnefn.301115_1.pdf (accessed March 25, 2021).

Stögner, K. 2020. Intersectionality and Antisemitism - A New Approach. Fathom. https:// fathomjournal.org/intersectionality-and-antisemitism-a-new-approach/ (accessed March 22, 2021).

Strømmen, H., and U. Schmiedel. 2020. The Claim to Christianity. Responding to the Far Right. London: Student Christian Movement (SCM) Press.

Tagliaferri, F. V. 2018. Tolerance Re-Shaped in the Early-Modern Mediterranean Borderlands: Travellers, Missionaries, and Proto-Journalists (1683-1724). New York: Routledge.

Tutino, S. 2006. "Between Nicodemism and 'Honest' Dissimulation: The Society of Jesus in England.” Historical Research 79 (206): 534-53.

Van der Tol, M. D. C. 2020. "Politics of religious diversity: Toleration, religious freedom and visibility of religion in public space." thesis, University of Cambridge.

Van der Tol, M. D. C. 2021. "Politics of Belonging in the Nation State: Reclaiming Christianity from Populism." In The Spirit of Populism: Political Theologies in Polarized Times, edited by J. Ralston, and U. Schmiedel, 57-69. Leiden: Brill.

Veenhof, J. 1968. Revelatie en Inspiratie. De Openbarings- en Schriftbeschouwing van Herman Bavinck in vergelijking met die der ethische theologie. Amsterdam: Buijten \& Schipperheijn.

Wallet, B. 2016. "Waarom het antisemitisme uiteindelijk niet aansloeg in the Nederlandse Christelijk- Sociale traditie." Sophie 3: 4.

Wolf-Schwarz, D., ed. (2002). Wege zur Toleranz. Geschichte einer europäischen Idee in Quellen. Darmstadt: Wissenschaftliche Buchgesellschaft. 
Wydra, H. 2015. Politics and the Sacred. Cambridge: Cambridge University Press.

Zagorin, P. 1990. Ways of Lying: Dissimulation, Persecution and Conformity in Early Modern Europe. Cambridge, Massachusetts: Harvard University Press.

\section{Bionote}

Mariëtta van der Tol is Alfred Landecker Postdoctoral Research Fellow at the Blavatnik School of Government and Junior Research Fellow at New College, Oxford. She completed her thesis is 'Politics of religious diversity: toleration, religious freedom and the visibility of religion in public space' in 2020 at the University of Cambridge. 